\title{
Yield Management As A Pricing Mechanism
}

María-Encarnación Andrés Martínez, University of Castilla-La Mancha, Spain Miguel-Ángel Gómez Borja, Ph.D., University of Castilla-La Mancha, Spain Juan-Antonio Mondéjar Jiménez, Ph.D., University of Castilla-La Mancha, Spain

\begin{abstract}
Consumers nowadays frequently make their purchases online. One common pricing strategy on the Internet is demand-based pricing, which allows firms to adapt prices to the demand for their products. This mechanism can undoubtedly be employed more efficiently on the Internet, due to how quickly demand information can be obtained.

Within demand-based pricing, one very well-known practice is yield management. This practice was pioneered by airlines, but has spread in recent years to industries such as hotels, rental cars and cruise lines to name but a few industries. The application of yield management was an authentic revolution for the traditional concept of pricing, but has shown that it can be a good strategy when used correctly. Applying yield management requires firms to understand consumer purchasing behavior in order to compare present demand with the demand that is anticipated in the future. Yield management techniques imply the allocation of a fixed capacity to different prices and segments of consumers in order to maximize income. Yield management is sometimes confused with a well-known segmentation strategy called time-based pricing. For this reason, in this paper we highlight the main demand-based pricing strategies that are now being used on the Internet, placing special emphasis on yield management.
\end{abstract}

Keywords: Internet; Pricing Mechanisms; Demand-Based Pricing; Yield Management

\section{INTRODUCTION}

¿ nternet consumers pay great attention to prices. This situation has been taken into account by the people that organize purchases online, which is why many of the efforts made in this channel have affected aspects related to the price of products and more specifically to pricing mechanisms. One frequently used pricing strategy on the Internet is demand-based pricing and more specifically, yield management.

Yield management is used a great deal at present and is an innovative pricing mechanism. The air transport industry has a long tradition in the application of this mechanism, as any mistakes in price fixing can have serious consequences for this type of company. If flights are assigned very high prices, the airplanes will take off halfempty. If flights are very cheap, airplanes will be full, but the company will have lost potential customers who would have paid more for a ticket. Yield management makes it possible to establish tariffs for each route (or even the same route) using a price fixing system based on demand.

Yield management could be defined as "a method that helps to sell the correct product to the appropriate consumer, at the suitable moment and price" (Kimes, 1994) or "prices established by paying attention to the different categories of consumers with the aim of being able to maximize yields" (Valls, 2009). Indeed, different consumers are willing to pay different tariffs for one same product. The same consumer may even accept different prices at different times. A business traveller who organizes his or her trip at the last moment accepts to pay a little more for an airplane ticket than tourists who have been planning their trip for months. Revenue management fixes the right price for each consumer segmented by spending power, tastes, habits and geographic location. According to RM Systems, this technique can increase sales by between $3 \%$ and $8 \%$ and profits by between $50 \%$ and $100 \%$. 
The primary question posed by the present economic scenario is how to use this strategy when there is a shortage of demand. Yield management has to date been confined to getting consumers to pay the highest possible price. Nevertheless, this technique does have a series measures and tools at its disposal, which optimize and maximize income in each case. Some of those tools are discussed below for the case of hotels:

1. Demand forecasting allows companies to measure demand in the future. Besides analyzing past data, occupation and average tariffs must be estimated for forthcoming months in order to; anticipate periods of low demand to adopt the appropriate saving measures and detect increases in demand to raise tariffs and optimize income during those periods.

2. Sale by category. For example: hotels must try to sell all the types of rooms on offer, clearly explaining the advantages of each. The fact that consumers may have more budget problems does not mean that they will not be willing to book a higher quality room if it suits their needs better.

3. Sell more services. In many cases, companies confined their efforts to selling the product, when additional services can be offered to increase customer satisfaction.

4. Total Revenue Management. We must analyze the total cost of a customer, not only the average tariff generated. Customers that pay less for the product (and which are therefore valued less), may spend on additional services, making them more profitable.

5. Segment analysis. If hotels analyze reservations by groups of consumers, they can obtain the maximum potential of each (individual, corporate consumer, travel agency, groups). The income lost in one segment can be offset by the income gained in another.

6. Pricing strategies. Studies performed after the last great crisis in the USA in 2001 show that lowering prices below those of the competition does not increase profits. Hotels must adapt tariffs to the conditions of the market, but avoid price wars.

This paper highlights the main characteristics of yield management as a pricing strategy. Hence, Section 2 presents the main pricing strategies. Sections 3 and 4 describe the yield management techniques and the conditions necessary to apply this strategy, while the last section details the main conclusions of the paper.

\section{PRICING MECHANISMS}

The Internet has both strategic and tactical advantages. It allows companies to improve price fixing in three different ways that are not available to offline companies:

1. Precise level and communication of prices. At this level, profits are large because companies can identify the range of prices within which consumers will be indifferent to changes. Therefore, the Internet allows companies to determine how variations in prices (increases or decreases) influence consumer perception.

2. Ability to adapt to any changes that take place in the market. Online price fixing undoubtedly provides companies with a great opportunity to adapt to market conditions. Companies can be flexible when it comes to setting prices, basing them on information obtained at the same time prices are fixed. For example: Tickets.com has increased its income by $45 \%$ using a dynamic price-fixing mechanism to set the prices of concert tickets according to supply and demand.

3. Price segmentation. The segmentation of prices is essential when fixing prices. In this sense, online companies can use different information sources, such as clickstream, which provide data on the present session in Internet, or cookies, which offer information on past purchases. Using these tools, it is possible to determine the best prices for each segment.

It is essential to emphasize the importance that consumers assign to the process used to fix prices. According to Dickson and Kalapurakal (1994), this process determines the perception of price fairness. In this sense, consumers want to understand how prices are fixed and when they cannot, they tend to perceive prices to be unfair, because the procedure is not clearly observable. There are three possible reasons why consumers do not understand price-fixing mechanisms: they do not understand changes in prices without a justified reason; they cannot forecast costs (i.e. the expenses that a company has), or they are incapable of estimating the real value of the product (i.e. what they obtain) (Nasr et al., 2009). 
As a result of the importance that price-fixing has acquired and the impact it has on price perception, some authors have analyzed different pricing mechanisms. When fixing prices, the following aspects have traditionally been considered essential: cost, demand and competition (e.g. Velasco, 1994; Miquel et al., 1994; Esteban et al., 2008). Each of these aspects is discussed below:

1) Cost-based price fixing mechanisms. There are several methods in this category: cost plus margin; price margin and target profit.

a) Cost plus margin is the simplest method to apply. This method consists of adding a margin to the total cost of producing the product, which is normally a percentage (profit margin), in order to obtain the final price of sale.

b) Price margin. In this case, the margin is not calculated on basis of cost, but rather price.

c) Target profit. This method consists of determining the price that makes it possible to attain a target profit.

2) Demand-based pricing mechanisms. When the demand for a product increases, its price also tends to rise, whereas in recessions it tends to decrease, despite the fact that costs do not vary. Normally, if a company raises its prices, sales will fall and vice-versa. However, there are some exceptions to this theory, such as luxury products, the sales of which increase when their prices go up. The most common demand-based price mechanisms are:

a) Price discrimination. This method consists of selling the same product at different prices, depending on the place, customer or time of the year.

b) Experimentation. In this case it is necessary to test several prices for the same product a different times to determine the impact of these prices on demand and therefore set the most suitable prices for the objectives of the company.

c) Intuition. In this case, prices are fixed by presuming the effects that prices are going to have on demand.

3) Competition-based pricing mechanisms. Prices are fixed in relation to the prices of the competition. So, companies fix their prices based on their position in the market. Prices can be higher, equal to or lower than the prices of the competition.

a) Higher prices. In this case, prices are higher than those of the competition if a well-known advantage is offered.

b) Similar or equal prices. This situation takes place when the product is perceived to be similar.

c) Lower prices. Prices are initially lower in order to enter a market that is dominated by the competition.

Besides the foregoing elements, authors such as Díez and Rosa (2008) add other factors which are also necessary to consider when it comes to deciding prices. They are: the characteristics of the supply offered by the company (product, price, distribution and the rest of marketing variables); company circumstances; technology; environment and, finally, information.

This research considers the price fixing methods that are based on demand, because they are the most frequently used on the Internet and also the most easily applicable to this environment. In this sense, the most used classifications of demand-based pricing mechanisms on the Internet are addressed in Huang et al. (2005). They considered three groups:

1. The first pricing model includes the negotiation that includes greater interaction between buyers and sellers where buyers have the power to negotiate prices, as well as to accept or reject them as they see fit. Unlike negotiations in the traditional channel, it is not necessary for buyers and sellers to meet in a specific place, as they can negotiate over the Internet. The group-buying discount is based on purchasing power. It consists of buying a large number of items to obtain lower prices (Dolan and Moon, 2000; Kauffman and Wang, 2001). These buying groups are formed for a set of buyers that are grouped to be able to obtain 
discounts and the best price. Therefore, the more members a group has, the more chances of obtaining lower prices.

2. The second group considered the price discrimination. In this model, different prices are offered according to consumer characteristics. Three different levels are distinguished. In the first level, prices are fixed according to previous purchases. In the second level, prices are fixed according to the quantity of items purchased; and in the third level, prices are determined according to geographical area or price sensitivity (for example: when consumers search for a product, they can establish the lowest price as a requisite, so that when they log onto a website they can find the lowest prices). Moreover, sellers can change their prices as in the case of random discounts or new consumers.

3. The third group is formed by the pricing strategy analysed in this paper; yield management. As we have said yield management consists of increasing or decreasing prices depending on the conditions of the market. In this sense, prices can be adapted considering aspects such as the moment a reservation is made or the demand at the time.

\section{YIELD MANAGEMENT}

The use of yield management is a practice that has become popular in many service industries. After the success in airlines, many firms (for example rental cars, hotels, cruises, etc...) have tried to adapt it to their businesses.

Applying yield management entails understanding consumers' purchasing behaviour in order to compare present demand with the demand that is anticipated in the future. This strategy identifies opportunities of sales and using the price, adjustments (rises or cuts) are made in order to ensure a balance between supply and demand (Relihan, 1989).

Yield management techniques imply the allocation of a fixed capacity to different prices to segments of consumers with the purpose of maximizing income. This strategy has been widely used by airlines in which the buyers that purchase their ticket in advance are more sensitive to prices. These consumers, in order to benefit from price discounts, need to accept restrictions, as well as penalties if they decide to make any change in relation to the purchase. On the other hand, the consumers who buy an airplane ticket at the last moment are less sensitive to prices. Therefore, they are prepared to pay a higher price in order to obtain a product considered as emergency. Yield management allows completing the capacity of a firm, contributing to the primary target, which is to maximize benefits (Coulter, 1999).

In this sense, many firms use computer-developed pricing mechanisms in order to achieve this goal. These systems are called Yield Management Systems (YMS) and use strategies such as: discounts when purchases are made in advance; overbooking, well-known in the airline industry, but also applied by hotels through reserving more rooms than there really are (Kimes, 1989); and establishing a date limit before when purchases will benefit from discounts. This results in different prices according to the time when the reservation is made. In this sense, Desiraju and Shugan (1999) analyzed in what conditions yield management assured gains. Results revealed that after identifying two segments in the market, consumers sensitive and insensitive to prices, which this strategy works better with the latter, who make last minute purchases than with consumers who are sensitive to prices. Moreover, another important aspect is being aware of the capacity of the firm in real time, because this makes it possible to adapt prices to the situation, in order to complete the capacity available and thus be able to maximize income (Desiraju and Shugan, 1999).

In line with this, Berman (2005) defined yield management as an effective mechanism for assigning a service with fixed capacity and a wide range of discounts, which has the basic principle of continuously updating prices in order to maximize profits. Therefore, the main aim of yield management is to adjust prices in order to complete available capacity, as the marginal cost of attending one more customer in many services is small. This practice usually divides time into two periods: one with discounts for reservations in advance and another aimed at consumers who are less sensitive to prices. 
Generally, the concepts of yield management and revenue management are used as synonyms in the services industry. However, revenue management is used more frequently in the hotel sector (Noone et al., 2003; Choi and Mattila, 2005; Noone and Mattila, 2009). This strategy can be used in several industries. In this sense, Marchionna (2005) considers its application in: airlines; hotels; wholesale tourism operators; restaurants and catering; urban and suburban transport; long-distance rail passenger transport; electricity distribution and generation; infrastructure use for freight transport; telephone services; use of roads and public streets; bed occupation in hospitals; use of operating theatres; and, finally, industries with inflexible production capacity and fluctuating demand. All these sectors have some elements in common: limited capacity; perishable products or services; the possibility of segmenting demand; and high overheads.

The changes in online prices when yield management is used are determined by market conditions (for example: present demand, time at which a service is received...). Then, yield management consists of discriminating at the time of fixing prices according to the demand that is predicted (Huang et al., 2005; Maxwell, 2008). Hence, it is possible to obtain different prices depending on the restrictions that are accepted. For example: in the purchase of an airplane ticket, the people who buy their ticket in advance normally pay less than those who do it later (Desiraju and Shugan, 1999; Huang et al., 2005).

This is the reason that yield management is sometimes confused with a well-known segmentation strategy called time-based pricing, despite being different strategies. Time-based pricing is a simpler strategy than yield management. It entails fixing different prices based on the time at which a service is received (for example: halfprice tickets on the day of a show or special prices for renting a car at the weekend in a big city). With yield management, on the other hand, prices can change at any time (day to day or in the case of an airline from flight to flight), in order to complete a firm's capacity. The main difference between the two strategies is that in time-based pricing, consumers who make their purchases at the same time pay the same price, unlike yield management (Berman, 2005).

Yield management techniques are based on previously segmenting the market to later establish different prices by segment in order to maximize income and available capacity (Selmi, 2010). Market segmentation is therefore a key element in yield management because profits usually increase when the number of market segments increase. However, one basic aspect is undoubtedly that the different segments do not perceive the use of this practice as unfair (Kimes, 2002).

One more general conception of yield management defines this model as a sophisticated way of directing supply or demand, based on manipulating rates and available capacity simultaneously. In this sense, available capacity can be assigned at a given time by monitoring demand segments and fixing prices according to the sensitivity of these segments to prices, assigning a lower price to the most sensitive of price segments and a higher price to those which display a greater willingness to pay more (Avlonitis and Indounas, 2007).

According to Blake and Buckhiester (2005), the success of revenue management depends on taking the following steps: create a revenue management group to be involved in decision making, as well as fixing prices; know the firm and its competitors, in the sense of being aware of what the firm offers to know whether or not the needs of consumers are being satisfied, as well as to know what services or products the competition is supplying; fix prices strategically, after analyzing what channels customers use to make their reservations; determine the most valuable consumers; and forecast demand, not only occupation.

On the basis of the previous points, we can consider two fundamental elements when developing a yield management strategy; knowing the characteristics of the consumer in order to adapt the supply accordingly and that all firm members know what they want to attain and are involved in the objectives that are pursued.

The success of using yield management depends mainly on the consumer, since the consumer is the axis. Therefore, decisions are based on the consumer (Shaw, 1992). Therefore, the following section shows the main factors that affect consumer price perception when yield management is used. Controlling these factors has a huge impact on how successful this strategy will be in both the short and long term. 


\section{CONDITIONS TO APPLY YIELD MANAGEMENT}

The requirements necessary to apply yield management correctly are as follows (Kimes, 2000): limited capacity; segmentation of the market; uncertainty in demand; perishable inventory and, finally, high overheads. It is possible to indicate that market segmentation figures prominently, because when the number of market segments increases, profits increase. However, the fundamental issue is without a doubt that the different segments do not perceive the use of this practice to be unfair (Kimes, 2002).

In this sense, Berman (2005) establishes situations in which the yield management strategy can be used. These situations must fulfill a series of characteristics in relation to demand, reservations, costs and capacity limit (see Table 1).

Table 1. Ideal situations to apply yield management

\begin{tabular}{|c|c|c|c|}
\hline Demand characteristics & Reservations & Cost characteristics & Capacity limit \\
\hline $\begin{array}{l}\text { - Significant variation in } \\
\text { demand by time of day, } \\
\text { season, day of week } \\
\text { - Demand that can be } \\
\text { segmented } \\
\text { - Significant differences in } \\
\text { price elasticity by market } \\
\text { segment }\end{array}$ & $\begin{array}{l}\text { - Predictable demand } \\
\text { - Service is booked by } \\
\text { consumers in different time } \\
\text { periods } \\
\text { - Uncertainty of actual usage } \\
\text { despite bookings creates } \\
\text { possibility of unsold seats }\end{array}$ & $\begin{array}{l}\text { - Low costs of marginal sales } \\
\text { in comparison to marginal } \\
\text { income } \\
\text { - High overheads }\end{array}$ & $\begin{array}{l}\text { - Capacity is really fixed. A } \\
\text { fixed number of units of } \\
\text { output must be allocated to } \\
\text { customers } \\
\text { - Service providers have } \\
\text { excess capacity at certain } \\
\text { times and excess demand at } \\
\text { other times } \\
\text {-Capacity is perishable. It } \\
\text { cannot be stored }\end{array}$ \\
\hline
\end{tabular}

Source: Adaptation of Berman (2005)

The success of yield management depends mainly on the customer, which is the axis on the basis of which strategic and price-fixing decisions must be taken (Shaw, 1992). According to Blake and Buckhiester (2005), in order to use yield management successfully, companies must take the following steps: create a yield management group that is involved in the decision making process, as well as in the fixation of prices; know the company and its competitors, that is, know what the company offers in order to ascertain whether consumer needs are being covered, as well as to know the services or products offered by the competition; fix prices strategically, once the company has analyzed how their customers make their reservations; determine the most valuable consumers and forecast demand.

In this sense, McMahon and Palmer (2000) consider the following actions necessary for the yield management strategy to be successful:

- Identify the base customer using a detailed process of segmentation, which becomes the first step towards finding the correct customer and, therefore, being able to offer them a suitable price.

- $\quad$ Make managers aware of the necessity to change customer needs and expectations.

- $\quad$ Consider the elasticity of price and demand by market segment.

- Make managers responsible for knowing the conditions of the market, which are characterized by constant change.

- $\quad$ And, finally, analyze past demand in combination with the reliability of the forecasting method.

According to Valls (2009) "when managing income on the basis of dynamic prices, there are a series of principles that must be applied":

a) Balance between supply and demand. This equilibrium is obtained by adjusting prices in order to reduce the seasonal component of demand, maximize capacity and avoid stocks.

b) Segmentation on the basis of price sensitivity. Create consumer segments according to their sensitivity to prices, and then fix prices according to each of these segments. 
c) Knowledge of the target market. Analyze past behavior to secure a precise knowledge of the market.

d) Modulation of price tariffs. Assess the opportunity of obtaining new income through the modulation of price tariffs.

On the basis of the above, two fundamental elements must be considered when developing a yield management strategy. On the one hand, companies must be aware of the characteristics of the target customer to better adapt their supply. On the other hand, the entire company must be aware of its objectives and be involved in accomplishing them.

\section{CONCLUSIONS}

The increasing use of the Internet as a channel for consumers to purchase products and services, along with the current worldwide economic crisis, has brought about an increase in the use of pricing strategies based on demand. The most popular of such strategies is yield management, which allows companies to maximize their profits by fixing prices dynamically on the basis of product demand.

When implementing this strategy, companies must take into account that certain conditions must be met, the most important being: the existence of limited capacity, as this makes it possible to justify variations in prices; the need to be able to segment the market so as to establish different prices for different consumers even when the product is the same and the existence of uncertainty in demand, because if demand is fixed, any price variations on the basis of demand would obviously always be constant.

This analysis has been undertaken to analyze the strategies that are used the most for online price fixing, with yield management figuring the most prominently. However, as a future line of research, we will consider the need to ascertain what consumers think about all this, as customer perception of pricing mechanisms plays a fundamental role in future purchasing decisions. As a result, it will be very interesting to analyze how consumers perceive this strategy.

\section{AUTHOR INFORMATION}

María-Encarnación Andrés Martínez, Degree in Business Administration by University of Castilla-La Mancha. Assistant Professor in Marketing at Business Administration Department. Faculty of Economics and Business Administration of Albacete. University of Castilla-La Mancha (Spain). E-mail: Encarnacion.Andres@uclm.es.

Research Interest: consumer behaviour, price perception, Internet and tourism.

Miguel-Ángel Gómez Borja, BS. Business Administration. School of Economics. University of Valencia (Spain). Phd. in Business and Economics. University of Castilla-La Mancha (Spain). Associate Professor of Marketing. School of Economics and Business Administration. University of Castilla-La Mancha. Albacete Campus (Spain). Phone: +34 967599200 x2309 Fax: + 34967599 216; E-Mail: miguelangel.gborja@uclm.es

Research interests: Consumer Behavior, Social Media Marketing, Pricing, Tourism Marketing, ICT and Marketing Research, New Technologies and Retailing, International Retailing, Non-Profit Marketing.

Juan-Antonio Mondéjar-Jiménez, $\mathrm{PhD}$ and Degree in Business Administration by University of Castilla-La Mancha. Degree in Advanced Studies in Marketing at the same university. Associate Professor in Marketing at Business Department. Faculty of Social Sciences of Cuenca. University of Castilla-La Mancha (Spain). E-mail: JuanAntonio.Mondejar@uclm.es

Research Interest: Consumer behavior, price perception, e-learning and tourism marketing. 


\section{REFERENCES}

1. Avlonitis, G. J. and Indounas, K. A. (2007): “An empirical examination of the pricing policies and their antecedents in the services sector", European Journal of Marketing, 41(7/8), pp. 740-764.

2. Berman, B. (2005): "Applying yield Management pricing to your service business", Business Horizons, 48(2), pp. 169-179.

3. Blake, K. and Buckhiester, B. (2005): Top five "must dos" to raise room profitability. Available in: www.hotelnewsresource.com/article16996.html. Accessed 02 June 2011.

4. Choi, S. and Mattila, A. (2005): "Impact of information on customer fairness perceptions of hotel revenue management", The Cornell Hotel and Restaurant Administration Quarterly, 46(4), pp. 444-451.

5. Coulter, K. (1999). "The application of airline yield management techniques to a holiday retail shopping setting”, Journal of Product and Brand Management, 8(1), pp. 61-72.

6. Desiraju, R. and Shugan, S. (1999): "Strategic service and yield management", Journal of Marketing, 63(1), pp. 44-56.

7. Dickson, P. and Kalapurakal, R. (1994): "The use and perceived price fairness of price-setting rules in the bulk electricity market", Journal of Economic Psychology, 15 (3), pp. 427-448.

8. Díez, E. C. and Rosa, I. M. (2008): Gestión de precios ( $5^{\text {th }}$ ed), Madrid, Esic.

9. Dolan, R. J. and Moon, Y. (2000): "Pricing and market making on the Internet", Journal of Interactive marketing, 14(2), pp. 56-73.

10. Esteban, A., García de Madariaga, J., Narros, M. J., Olarte, C., Reinares, E. M. and Saco, M. (2008): Principios de Marketing ( ${ }^{\text {rd }}$ ed.), Madrid, Esic.

11. Huang, J. H., Chang, C. T. and Chen, C. (2005): "Perceived Fairness of pricing on the Internet", Journal of Economic Psychology, 26(1), pp. 343-361.

12. Kauffman, R. J. and Wang, B. (2001): "New buyers' arrival under dynamic pricing market microstructure: The case of group-buying discounts on the Internet", Journal of Management Information System, 18 (2), pp. $157-188$.

13. Kimes, S. E. (1989): "Yield management: a tool for capacity-constrained service firms", Journal of operations management, 8, pp. 348-363.

14. Kimes, S. E. (1994): "Perceived fairness of yield management", The Cornell Hotel and Restaurant Administration Quarterly, 35(1), pp. 22-29.

15. Kimes, S. E. (2000): “A strategic approach to yield management”, in A. Ingold, I. Yeoman and U. McMahon-Beatie (ed.) Yield management: strategies for the service industries, Thomson Business Press.

16. Kimes, S. E. (2002): "Perceived fairness of yield management", Cornell Hotel and Restaurant Administration Quarterly, 43(1), pp. 21-30.

17. McMahon, B. and Palmer, A. (2000): "One for all or all for one: a comparison of everyday low pricing and yield management strategies in the hotel industry", Journal of Targeting, Measurement and Analysis for Marketing, 8 (3), pp. 249-258.

18. Marchionna, A. (2005): “Una visión estratégica sobre el Revenue Management”, Instituto Superior de Hotelería y Restaurateur 5, pp.10-17. Available in: http://campus.ishyr.com.ar/index.cgi. Accessed 02 June $\underline{2011 .}$.

19. Maxwell, S. (2008): The price is wrong: understanding what makes a price seem fair and the true cost of unfair pricing, New Jersey, John Wiley \& Sons.

20. Miquel, S., Mollá, A. and Bigné, J. E. (1994): Introducción al Marketing, Madrid, McGraw-Hill.

21. Nasr, N. B., Sisodia, R. S. and Sheth, J. N. (2009): "Developing a model of antecedents to consumers'perceptions and evaluations of price unfairness", Journal of Business Research, 62 (8), pp. 761767.

22. Noone, B. M., Kimes, S. E. and Renaghan, L. M. (2003): "Integrating customer relationship management and revenue management: a hotel perspective", Journal of Revenue and Pricing Management, 2(1), pp. 7 22.

23. Noone, B. M. and Mattila, A. S. (2009): "Hotel revenue management and the Internet: The effect of price presentation strategies on customers' willingness to book", International Journal of Hospitality Management, 28(2), pp. 272-279.

24. Relihan, W. J. (1989): "The yield-management approach to hotel-room pricing”, The Cornell Hotel and Restaurant Administration Quarterly, 30(1), pp. 40-45. 
25. Selmi, N. (2010): "Effects of culture and service sector on customer's perceptions of the practice of yield management", International Journal of Marketing Studies, 2(1), pp. 245-253.

26. Shaw, M. (1992): "Positioning and price: Merging theory, strategy, and tactics", Journal of Hospitality \& Tourism Research, 15(2), pp. 31-39.

27. Valls, J. F. (2009): "Precios estáticos y precios dinámicos", Harvard Deusto Finanzas y Contabilidad, 88, pp. 52-61.

28. Velasco, E. (1994): El precio: variable estratégica de marketing, Madrid, McGraw-Hill. 


\section{NOTES}

